\title{
Evaluation of the Efficacy of Chemical Method to Determine Urinary Tract Stone Composition
}

\author{
Önder Kara, ${ }^{1}$ Ercan Malkoç, ${ }^{2}$ Şenol Tonyalı, ${ }^{3}$ Ferhat Ateş, ${ }^{2}$ \\ Ali Serdal Uyumaz, ${ }^{4}$ Ömer Özcan, ${ }^{4}$ Zeki Aktaş, ${ }^{2}$ Temuçin Şenkul ${ }^{2}$
}

\footnotetext{
'Department of Urology, Amasya University Faculty of Medicine Amasya, Turkey

${ }^{2}$ Department of Urology, Gülhane Military Medical Academy, Haydarpaşa Training Hospital, İstanbul, Turkey

${ }^{3}$ Department of Urology, Türkiye Yüksek İhtisas Training and Research Hospital, Ankara, Turkey ${ }^{4}$ Department of Biochemistry, Gülhane Military Medical Academy, Haydarpaşa Training Hospital, İstanbul, Turkey

Submitted: 30.01.2016 Accepted: 16.05.2016

Correspondence: Önder Kara, Amasya Üniversitesi Tıp Fakültesi,

Üroloji Anabilim Dalı, 05100 Amasya, Turkey

E-mail: onerkara@yahoo.com

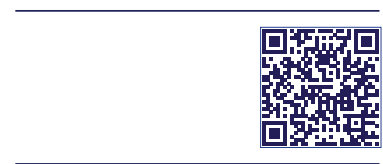

Keywords: Nephrolithiasis; spectroscopy; stone analysis.
}

\begin{abstract}
Objective: The present study evaluated use of chemical method to determine components and category of urinary stones described in current stone disease guidelines.

Methods: Chemical analysis of total of 198 urinary stones was performed between March 2014 and September 20I5. Calcium, oxalate, uric acid, magnesium, phosphate, cysteine, ammonium, and carbonate were among components detected in stone composition. Stones were divided into groups based on presence of I, 2, or 3 or more components. Composition results were compared with stone composition data provided in global guidelines.
\end{abstract}

Results: Sixty-five (32.9\%) samples consisted of I mineral and I 33 (67.I\%) contained more than I. Of the total, 107 (54\%) compositions were included in European Association of Urology (EAU) guidelines. The 107 samples included 45 (22.7\%) with components of calcium oxalate, 22 (II.6\%) of calcium phosphate, II (6.I\%) of calcium and uric acid, 10 (5\%) of uric acid, 7 (3.5\%) of cysteine, 7 (3.5\%) of carbonate apatite, 4 (2\%) of ammonium urate, and I $(0.5 \%)$ of magnesium, ammonium, and phosphate. However, 91 (46\%) stones consisted of components that are not in current EAU guidelines.

Conclusion: Chemical analysis was found insufficient to categorize stone types and components seen in EAU guidelines. There is also a lack of information on the process in the literature. It was concluded that chemical analysis is not the best method to evaluate urinary stones.

\section{INTRODUCTION}

Urinary system stone disease is more frequently seen in developed countries, with prevalence that varies between $1 \%$ and $20 \%{ }^{[1,2]}$ In addition to obesity, metabolic syndrome, and type 2 diabetes, ${ }^{[3,4]}$ factors such as calcium-deficient diet, and diet rich in salt and animal protein increase the incidence of the disease. [2,5] More than 100 chemical components have been defined in urinary system stones; however, multiple underlying molecular mechanisms of the disease have not been clarified yet. ${ }^{[6]}$ Stone analysis is important in order to be able to prevent recurrence. In all cases of recurrence ${ }^{[2,7]}$ following long-term stone-free period achieved with pharmacological treatment, chemical analysis of the stone is recommended. ${ }^{[2]}$ Since most urinary system stones are composed of complex components, chemical methods of analysis frequently prove to be inadequate. ${ }^{[8,9]}$ Methods of stone analysis currently used include infrared spectroscopy (IRS), $X$-ray diffraction (XRD), and polarization micros- 
Table 1. Types of stones and components detected in the study

\begin{tabular}{|c|c|c|c|}
\hline \multirow[t]{2}{*}{$\mathrm{n}$} & \multirow[t]{2}{*}{$\%$} & \multicolumn{2}{|c|}{ Stones described in EAU guidelines ( $n=107 ; 54 \%$ ) } \\
\hline & & Stone composition & $\begin{array}{l}\text { Chemical symbol for mineral } \\
\text { composition of stone }\end{array}$ \\
\hline 45 & 22.7 & Calcium oxalate & $\mathrm{CaOx}$ \\
\hline 22 & 11.6 & Calcium phosphate & $\mathrm{CaPO}_{4}$ \\
\hline 11 & 6 & Calcium + uric acid & $\mathrm{Ca}+\mathrm{C}_{5} \mathrm{H}_{4} \mathrm{~N}_{4} \mathrm{O}_{3}$ \\
\hline 10 & 5 & Uric acid & $\mathrm{C}_{5} \mathrm{H}_{4} \mathrm{~N}_{4} \mathrm{O}_{3}$ \\
\hline 7 & 3.5 & Cysteine & {$\left[\mathrm{SCH}_{2} \mathrm{CH}\left(\mathrm{NH}_{2}\right) \mathrm{COOH}\right]_{2}$} \\
\hline 7 & 3.5 & Carbonate apatite & \\
\hline 4 & 2 & Ammonium muriate & $\mathrm{NH}_{4} \mathrm{C}_{5} \mathrm{H}_{3} \mathrm{~N}_{4} \mathrm{O}_{3}$ \\
\hline \multirow[t]{3}{*}{1} & 0.5 & Magnesium ammonium phosphate & $\mathrm{MgNH}_{4} \mathrm{PO}_{4}$ \\
\hline & & \multicolumn{2}{|l|}{ Stones not in EAU guidelines ( $n=91 ; 46 \%)$} \\
\hline & & Stone composition & $\begin{array}{l}\text { Chemical symbol for mineral } \\
\text { composition of stone }\end{array}$ \\
\hline 27 & 13.6 & Magnesium phosphate & $\mathrm{MgPO}_{4}$ \\
\hline 22 & 11.1 & Phosphate & $\mathrm{PO}_{4}$ \\
\hline 18 & 9 & Magnesium & $\mathrm{Mg}^{4}$ \\
\hline 10 & 5 & Magnesium calcium phosphate & $\mathrm{MgCa} \mathrm{PO}_{4}$ \\
\hline 5 & 2.5 & Calcium magnesium & $\mathrm{CaMg}$ \\
\hline 2 & 1 & Magnesium ammonium & $\mathrm{MgNH}_{4}$ \\
\hline 2 & 1 & Ammonium phosphate & $\mathrm{NH}_{4} \mathrm{PO}_{4}^{4}$ \\
\hline 2 & 1 & Uric acid phosphate & $\mathrm{C}_{5} \mathrm{H}_{4} \mathrm{~N}_{4} \mathrm{O}_{3}-\mathrm{PO}_{4}$ \\
\hline 1 & 0.5 & Ammonium urate phosphate & $\mathrm{NH}_{4} \mathrm{C}_{5} \mathrm{H}_{3} \mathrm{~N}_{4} \mathrm{O}_{3}-\mathrm{PO}_{4}$ \\
\hline 1 & 0.5 & Magnesium ammonium calcium & $\mathrm{MgNH}_{4} \mathrm{Ca}$ \\
\hline 1 & 0.5 & Calcium phosphate magnesium urate & $\mathrm{CaPO}_{3} \mathrm{MgNH}_{4} \mathrm{C}_{5} \mathrm{H}_{3} \mathrm{~N}_{4} \mathrm{O}_{3}$ \\
\hline
\end{tabular}

EAU: European Association of Urology.

cope. Although not very popular, chemical analysis ("wet" analysis) can also be used. . $^{[2,10]}$

This study was an investigation of the effectiveness of chemical method for analysis of components and categorization of urinary stones as described in current European Association of Urology (EAU) guidelines.

\section{PATIENTS AND METHODS}

Chemical analysis of stones was performed in the clinical biochemistry laboratory of Gülhane Military Medical Academy with the approval of the Gülhane Military Medical Academy Ethics Committee between March 2014 and September 2015. Stone samples brought in by patients and those removed using ureteroscopy or during percutaneous renal surgery were crushed into small fragments with mechanical lithotriptors. Fragments were then divided among 8 test tubes. Compo- sition of urinary system stone was analyzed according to instructions of LTA Kidney Stone Analysis Kit manufacturer (AB Analitica, Padova, Italy). Calcium, oxalate, magnesium, phosphate, uric acid, ammonium, cysteine, and carbonate found in the stones were analyzed quantitatively. Any stones too small to be divided among 8 test tubes were not included in the analysis. Results of chemical analysis were retrospectively analyzed. Stones were grouped according to number of mineral components: I, 2 or $\geq 3$. Components were compared with types of stone described in guidelines.

\section{RESULTS}

A total of 198 urinary system stones were analyzed. Majority $(n=133 ; 67.1 \%)$ consisted of multiple mineral components, while single component was found in remainder $(n=65 ; 32.9 \%)$. 
Table 2. Contents of stones described in EAU 2015 guidelines

\begin{tabular}{|c|c|}
\hline Stone composition & Chemical symbols of stone contents \\
\hline Calcium oxalate monohydrate (whewellite) & $\mathrm{CaC}_{2} \mathrm{O}_{4} \cdot \mathrm{H}_{2} \mathrm{O}$ \\
\hline Calcium oxalate dihydrate (wheddelite) & $\mathrm{CaC}_{2} \mathrm{O}_{4} \cdot 2 \mathrm{H}_{2} \mathrm{O}$ \\
\hline Basic calcium phosphate (apatite) & $\mathrm{Ca}_{10}\left(\mathrm{PO}_{4}\right)_{6} \cdot(\mathrm{OH})_{2}$ \\
\hline Calcium hydroxyphosphate (carbonite apatite) & $\mathrm{Ca}_{5}\left(\mathrm{PO}_{3}\right)_{3}(\mathrm{OH})$ \\
\hline Beta-tricalcium phosphate (whitlockite) & $\mathrm{Ca}_{3}\left(\mathrm{PO}_{4}\right)_{2}$ \\
\hline Carbonate apatite phosphate (dahllite) & $\mathrm{Ca}_{5}\left(\mathrm{PO}_{4}\right)_{3} \mathrm{OH}$ \\
\hline Calcium hydrogen phosphate (brushite) & $\mathrm{PO}_{4 \cdot 2} \cdot \mathrm{H}_{2} \mathrm{O}$ \\
\hline Calcium carbonate (aragonite) & $\mathrm{CaCO}_{3}$ \\
\hline Octacalcium phosphate & $\mathrm{Ca}_{8} \mathrm{H}_{2}\left(\mathrm{PO}_{4}\right)_{6} \cdot 5 \mathrm{H}_{2} \mathrm{O}$ \\
\hline Uric acid (uricite) & $\mathrm{C}_{5} \mathrm{H}_{4} \mathrm{~N}_{4} \mathrm{O}_{3}$ \\
\hline Uric acid hydrate (uricite) & $\mathrm{C}_{5} \mathrm{H}_{4} \mathrm{O}_{3}-2 \mathrm{H}_{2} \mathrm{O}$ \\
\hline Ammonium urate & $\mathrm{NH}_{4} \mathrm{C}_{5} \mathrm{H}_{3} \mathrm{~N}_{4} \mathrm{O}_{3}$ \\
\hline Sodium acid urate monohydrate & $\mathrm{NaC}_{5} \mathrm{H}_{3} \mathrm{~N}_{4} \mathrm{O}_{3} \cdot \mathrm{H}_{2} \mathrm{O}$ \\
\hline Magnesium ammonium phosphate (struvite) & $\mathrm{MgNH}_{4} \mathrm{PO}_{4} \cdot 6 \mathrm{H}_{2} \mathrm{O}$ \\
\hline Magnesium acid phosphate trihydrate (newberyite) & $\mathrm{MgHPO}_{4} \cdot 3 \mathrm{H}_{2} \mathrm{O}$ \\
\hline Magnesium ammonium phosphate monohydrate (dittmarite) & $\mathrm{MgNH}_{4}\left(\mathrm{PO}_{4}\right) \cdot 1 \mathrm{H}_{2} \mathrm{O}$ \\
\hline Cysteine & {$\left[\mathrm{SCH}_{2} \mathrm{CH}\left(\mathrm{NH}_{2}\right) \mathrm{COOH}\right]_{2}$} \\
\hline Gypsum & $\mathrm{CaSO}_{4} \cdot 2 \mathrm{H}_{2} \mathrm{O} \mathrm{Zn_{3 }}\left(\mathrm{PO}_{4}\right)_{2} \cdot 4 \mathrm{H}_{2} \mathrm{O}$ \\
\hline \multicolumn{2}{|l|}{ Xanthine } \\
\hline \multicolumn{2}{|l|}{ 2,8-Dihydroxyadenine } \\
\hline \multicolumn{2}{|l|}{ Proteins } \\
\hline \multicolumn{2}{|l|}{ Cholesterol } \\
\hline \multicolumn{2}{|l|}{ Calcite } \\
\hline \multicolumn{2}{|l|}{ Potassium urate } \\
\hline \multicolumn{2}{|l|}{ Trimagnesium phosphate } \\
\hline \multicolumn{2}{|l|}{ Melamine } \\
\hline \multicolumn{2}{|l|}{ Matrix } \\
\hline \multicolumn{2}{|l|}{ Medication stones } \\
\hline Foreign body stone & \\
\hline
\end{tabular}

Reprinted courtesy of Turk C., Knoll T., Petrik A., Sarica K., Skolarikos A., Straub M., et al. Guidelines on urolithiasis. European Association of Urology (EAU) 2015.

Analysis results of 107 (54\%) samples were consistent with EAU guideline description. Composition consisted of calcium oxalate $(n=45 ; 22.7 \%)$, calcium phosphate $(n=22 ; 11.6 \%)$, calcium and uric acid $(n=11 ; 6.1 \%)$, uric acid $(n=10 ; 5 \%)$, cysteine $(n=7$; $3.5 \%)$, carbonate apatite $(n=4 ; 2 \%)$, ammonium urate $(n=4 ; 2 \%)$, and magnesium ammonium phosphate $(n=1 ; 0.5 \%)$.

Chemical analysis of 91 (46\%) stone samples revealed mineral components and combinations of components that are not in current EAU guidelines, including magnesium phosphate $(n=27 ; 13.6 \%)$; phosphate $(\mathrm{n}=22 ; 1 \mathrm{I} .1 \%)$; magnesium $(\mathrm{n}=18 ; 9 \%)$; magnesium, calcium, and phosphate $(n=10 ; 5 \%)$; calcium and magnesium $(n=5 ; 2.5 \%)$; magnesium and ammonium $(n=2$; $1 \%)$; ammonium phosphate $(n=2: 1 \%)$; uric acid and phosphate $(n=2 ; 1 \%)$, ammonium phosphate and urate $(n=I ; 0.5 \%)$; magnesium, ammonium, and calcium $(n=I ; 0.5 \%)$; and calcium phosphate, magnesium, and urate $(n=I ; 0.5 \%)$ (Table I).

\section{DISCUSSION}

Urinary system stone disease is a prevalent health problem affecting millions of people worldwide. 
In developed countries, most often upper urinary system stones are seen; however, in developing countries, endemic infantile bladder lithiasis may be seen. ${ }^{[l]}$ Prevalence rate of stone disease in the United States of America has been reported as nearly $12 \%$ and $6 \%$ among male and female populations, respectively. ${ }^{\left[{ }^{11]}\right.}$ Turkey has a high (15\%) incidence of urinary system stone disease. ${ }^{[2]}$ Furthermore, high recurrence rate within 5 and 10 years after first painful episode of stone disease $(50 \%$ and $80-90 \%$, respectively) mandates pursuit of an effective strategy for diagnosis, treatment, and follow-up of this disease. ${ }^{[13]}$ In order to prevent not only urinary system diseases, but also bone, parathyroid, and many endocrine disorders, as well as their related complications, metabolic evaluation guidelines should be complied with, and stone analysis should be first among these assessments. For correct classification, in addition to evaluation of basic laboratory tests, urinalysis, i.e., microscopic examination of urine sample and/ or urine culture, serum creatinine, uric acid, calcium, sodium, potassium, C-reactive protein (CRP), whole blood count, and a reliable stone analysis should be performed. ${ }^{[2,14]}$ Variation in composition of stone from initial sample may occur over time, and subsequent stone may be of still another composition; therefore, analysis should be repeated in recurrent cases. ${ }^{[15,16]}$ Stone analysis can reveal risk factors for stone disease, as well as identify treatment targeted to prevent stone formation or dissolve an existing stone (litholysis). ${ }^{[10]}$ Stones containing brushite $\left(\mathrm{CaHPO}_{4} \cdot 2 \mathrm{H}_{2} \mathrm{O}\right)$, uric acid, and urate signal high risk for recurrence. ${ }^{[2]}$ Stone analysis assists in establishment of diagnosis of specific metabolic disorders and can indicate if the patient would benefit from shock wave lithotripsy. In addition, it can reveal drug metabolites, such as triamterene and indanavir, which can induce stone formation. ${ }^{[15]}$

Method to be used for stone analysis may vary according to type of sample, cost-effectiveness of method, lengthy duration of analysis, and experience of the analyst. ${ }^{[17]}$ Most frequently used methods of stone analysis include XRD, IRS, and polarization microscope. Each method has its own advantages and disadvantages. ${ }^{[10,18]}$ Low error rate and cost-effectiveness have made IRS most preferred method. ${ }^{[19]}$ Rapid results and ability to analyze even small stones with high degree of accuracy are additional advantages of this method. ${ }^{[19]}$ Chemical stone analysis method permits quantitative and qualitative determination of li- mited number of ions. It does not allow for identification of crystaloid structures. For instance, it cannot discriminate between calcium oxalate monohydrate and dihydrate stones. Furthermore, chemical analysis cannot identify xanthine, 2,8-Dihydroxyadenine, or medication-related stones. Error rates for this method have been reported as $6-94 \%$ and $13-47 \%$ for stones with I and 2 mineral components, respectively. ${ }^{[19]}$

In our study, 107 (54\%) stones with single or multiple mineral components as detected by our chemical analysis were in accordance with stone types indicated in EAU guidelines (Table 2), while 9I (46\%) were not described in the guidelines. Most frequently, calcium oxalate $(22 \%)$ and calcium phosphate (I $1.6 \%)$ stones were detected. In another study performed in this country with 6453 patients, most common types of stones found were whewellite (calcium oxalate monohydrate) (55.7\%), whellite plus weddellite (calcium oxalate dihydrate) ( $18.8 \%)$, and weddellite: $5.9 \%) \cdot{ }^{[12]}$

Data we obtained as a result of chemical method of analysis of urinary system stones were not consistent with the literature data, and did not meet current guidelines. Stone composition has important role in patient monitoring, appropriate dietary recommendations, and arrangement of pharmacotherapies, and should be determined with greater accuracy. Inaccurate results may lead to problems in diagnosis, treatment, and follow-up.

\section{Conclusion}

Urinary system stone disease is a widely seen health problem. Stone analysis is an indispensable part of diagnosis and treatment of this disease. Since treatment is different depending on stone type, establishment of accurate analysis and diagnosis is of utmost importance. Quantitative analysis is possible using chemical methods; however, if sample of adequate size is not available and test cannot be completed in its entirety, results obtained cannot be interpreted. Although chemical methods had been used frequently in the past, its use should be abandoned under current conditions because of its many disadvantages. University and training and research hospitals should be supported regarding need to have appropriate stone analyzers.

Conflict of interest

None declared. 


\section{REFERENCES}

1. Trinchieri A. Epidemiology of urolithiasis: an update. Clin Cases Miner Bone Metab 2008;5:101-6.

2. Türk C, Petř́k A, Sarica K, Seitz C, Skolarikos A, Straub M, et al. EAU Guidelines on Interventional Treatment for Urolithiasis. Eur Urol 2016;69:475-82.

3. Scales CD Jr, Smith AC, Hanley JM, Saigal CS; Urologic Diseases in America Project. Prevalence of kidney stones in the United States. Eur Urol 2012;62:160-5.

4. Kohjimoto Y, Sasaki Y, Iguchi M, Matsumura N, Inagaki T, Hara I. Association of metabolic syndrome traits and severity of kidney stones: results from a nationwide survey on urolithiasis in Japan. Am J Kidney Dis 2013;61:923-9.

5. Borghi L, Schianchi T, Meschi T, Guerra A, Allegri F, Maggiore $\mathrm{U}$, et al. Comparison of two diets for the prevention of recurrent stones in idiopathic hypercalciuria. $N$ Engl J Med 2002;346:77-84.

6. Daudon M, Doré JC, Jungers P, Lacour B. Changes in stone composition according to age and gender of patients: a multivariate epidemiological approach. Urol Res 2004;32:241-7.

7. Osther PJ, Grenabo L, Haraldsson G, Holmberg G, Lindell $\mathrm{O}$, Mogensen P, et al. Metabolic evaluation and medical management of upper urinary tract stone disease. Guidelines from the Scandinavian Cooperative Group for Urinary Stones. Scand J Urol Nephrol 1999;33:372-81.

8. Maurice-Estepa L, Levillain P, Lacour B, Daudon M. Crystalline phase differentiation in urinary calcium phosphate and magnesium phosphate calculi. Scand J Urol Nephrol 1999;33:299-305.
9. Meria P, Hadjadj H, Jungers P, Daudon M; Members of the French Urological Association Urolithiasis Committee. Stone formation and pregnancy: pathophysiological insights gained from morphoconstitutional stone analysis. J Urol 2010;183:1412-6.

10. Schubert G. Stone analysis. Urol Res 2006;34(2):146-50.

11. Curhan GC. Epidemiology of stone disease. Urol Clin North Am 2007;34:287-93.

12. Karabacak OR, Dilli A, Saltaş H, Yalçınkaya F, Yörükoğlu A, Sertçelik MN. Stone compositions in Turkey: an analysis according to gender and region. Urology 2013;82:532-7.

13. Uribarri J, Oh MS, Carroll HJ. The first kidney stone. Ann Intern Med 1989;111:1006-9.

14. Hesse A, Kruse R, Geilenkeuser WJ, Schmidt M. Quality control in urinary stone analysis: results of 44 ring trials (1980-2001). Clin Chem Lab Med 2005;43:298-303.

15. Kourambas J, Aslan P, Teh CL, Mathias BJ, Preminger GM. Role of stone analysis in metabolic evaluation and medical treatment of nephrolithiasis. J Endourol 2001;15:181-6.

16. Mandel N, Mandel I, Fryjoff K, Rejniak T, Mandel G. Conversion of calcium oxalate to calcium phosphate with recurrent stone episodes. J Urol 2003;169:2026-9.

17. Giannossi ML. The optimal choice for stone analysis. J Xray Sci Technol 2015;23:401-7.

18. Smith CL. Renal stone analysis: is there any clinical value? Curr Opin Nephrol Hypertens 1998;7:703-9.

19. Kravdal G, Helgø D, Moe MK. Infrared spectroscopy is the gold standard for kidney stone analysis. Tidsskr Nor Laegeforen 2015;135:313-4.

\section{Kimyasal Yöntemle Yapılan Üriner Sistem Taş Analizinin Taşı Tanımlamadaki Etkinliğinın Araştırılması}

Amaç: Bu çalışmada, üriner sistem taşlarının analizinde kullanılan kimyasal yöntemin güncel taş hastalığı kılavuzlarında yer alan taş tip ve bileşenlerini kategorize etmedeki etkinliği araştırıldı.

Gereç ve Yöntem: Mart 2014 ile Eylül 2015 tarihleri arasında toplam 198 üriner sistem taşının kimyasal incelemesi yapıldı. Kimyasal yöntemde taş içeriğinde bulunan kalsiyum, oksalat, ürik asit, magnezyum, fosfat, sistin, amonyum ve karbonat tespit edilebilmektedir. Bu yöntemle tespit edilen taş mineral içerikleri tek, iki, üç ve daha fazla komponent olarak gruplandırıldı. Elde edilen taş bileşenleri kılavuzlarda evrensel olarak sınıflandırıımış taş çeşitleri ile uygunluğu açısından kıyaslandı.

Bulgular: İnceleme sonunda 65 (\%32.9) örnekte tek mineral, 133 (\%67.I) örnekte ise birden fazla mineral içeriği saptandı. 45 (\%22.7) kalsiyum oksalat, 22 (\% I I.6) kalsiyum fosfat, II (\%6.I) kalsiyum + ürik asit, I0 (\%5) ürik asit, 7 (\%3.5) sistin, 7 (\%3.5) karbonat apatit, 4 (\%2) amonyum ürat, I (\%0.5) magnezyum amonyum fosfat olmak üzere 107 (\%54) örnek EAU (European Association of Urology) kılavuzundaki taş çeşitlerinde adı geçen örneklerle uyum gösteriyordu. Ancak 9I (\%46) örnekteki taş analizleri bu kılavuzda yer almayan kombinasyonlardan oluşuyordu.

Sonuç: Kimyasal taş analizi literatürde belirtilen eksikliklerinin yanında taş kılavuzlarında yer alan taş tip ve bileşenlerini kategorize etmede yetersiz olarak değerlendirildi. Kimyasal yöntem özellikle ilk tanı esnasında taşın değerlendirilmesi amacıyla tercih edilecek bir yöntem gibi görünmemektedir.

Anahtar Sözcükler: Nefrolitiazis; spektroskopi; taş analizi. 